\title{
Study on Influencing Factors and Mechanism of Entrepreneurial Motivation of College Students in the New Normal
}

\author{
Wenzhi Peng \\ Jingdezhen Ceramic Institute \\ Jingdezhen, Jiangxi, China 333403
}

\author{
Lei Huang \\ Jingdezhen Ceramic Institute \\ Jingdezhen, Jiangxi, China 333403
}

\begin{abstract}
Under the background of the increasingly serious situation in employment for college students, the entrepreneurship of college students has become an important education and social problem to which both the state and college students pay more attentions. As the prerequisite for college students to start a business, the entrepreneurial motivation has a direct influence on the development and follow-up development of college students during the business exploitation. Aiming at this point, this article conducts studies and analysis on influencing factors and mechanism for the entrepreneurship of college students, and analyzes main factors that influence the entrepreneurial motivation of college students through factor analysis. The empirical results show that the entrepreneurship environment, self efficiency and individual characteristics have different roles in the entrepreneurial motivation of college students.
\end{abstract}

Keywords-local colleges and universities, entrepreneurial motivation; influencing factors; empirical

\section{INTRODUCTION}

With the increasingly serious situation in employment, a great number of college students, facing the difficulty in employment, decide on entrepreneurship, which has become an important issue that the state and the CPC Central Committee are concerned about, most of local governments have released policies to encourage the entrepreneurship of college students. Under the New Normal, the entrepreneurship of college students is directly driven by the entrepreneurial motivations. For the "newcomers" to the society, the entrepreneurial motivation is an important catalyst that directly affects the success or failure of the entrepreneurship of college students. Accordingly this article analyzes the influencing factors and mechanism of college students' entrepreneurial motivations, analyzes main factors that influence the motivations and the mechanism of the factors.

Fund Project: Research Topic of Teaching Reform in Colleges and Universities in Jiangxi Province (Project No: JXJG-13-11-21); Research Topic of Teaching Reform in Colleges and Universities in Jiangxi Province (Project No: JXJG-14-11-6).

\author{
Lidong Zhang \\ Jingdezhen Ceramic Institute \\ Jingdezhen, Jiangxi, China 333403
}

\section{MAIN THEORIES CONCERNED}

There are many researches on the entrepreneurship of college students at home and abroad, in most literatures, the research mainly aims at three aspects namely definition of entrepreneurship, significance, entrepreneurship mechanism and motivation. In the research on the entrepreneurial motivations, most of foreign scholars are based on the entrepreneurship framework and theories to analyze the entrepreneurial motivations, for example, Forbes (2005) thinks that the entrepreneurial motivation is a prerequisite for innovation, the success or failure of entrepreneurship will have a close and important relationship with the entrepreneurial motivations.

Barbosa (2007) believes that self efficiency is the most important factor for the entrepreneurship of college students, which plays an important and guiding role in the success of entrepreneurship of college students. Hmieleski (2008), through comparing the entrepreneurial motivations between Japanese new \& high-tech corporations and that in the US Silicon Valley, found that the former was much more influenced by the social entrepreneurship environment, while the latter by individual characteristics.

Compared with foreign researches in the entrepreneurial motivations, China has no deep researches concerned. Xing Wenzhi (2014) thinks that the entrepreneurship is of obvious uncertainty, entrepreneurs often stop the business in progress due to the lack of entrepreneurial motivations, besides, she points out that the entrepreneurial environment, and entrepreneurial spirit and quality are important conditions to promote entrepreneurial success. Xiang Cheng (2015) Research results show that the entrepreneurial motivations are mainly divided into internal and external factors, of which, state policies and other business environment are important external factors, and self efficiency perception and goal orientation are two important factors influencing the internal entrepreneurial motivation. Wu Dongfang and Zhou Lian (2015) analyzed the factors influencing the entrepreneurial 
motivation through factor analysis, and the results showed that during the entrepreneurship, education background, entrepreneurial guidance, personal goals, independence and family income were main factors influencing the entrepreneurial motivation, of which, family income and individual goals were the two most important factors.

In a word, domestic researches concerning the entrepreneurial motivations are mostly based on the concepts, only a few adopt statistical methods to conduct empirical researches on factors, accordingly this article, based on the factor analysis, conducts researches on the influencing factors and mechanism of the entrepreneurial motivations from entrepreneurial environment, self efficiency, entrepreneurial characteristics.

\section{BACKGROUND FOR ENTREPRENEURSHIP OF COLLEGE STUDENTS}

\section{A. Background}

1) Pressure in Employment: With the increasing number of college graduates and the imbalance in the professional and industrial structures of higher education in the country, the employment situation is becoming more and more severe in China, Fig 1 shows that college graduates totaled 1.14 million in 2001, which increased to 7.49 million in 2015 , increased by $557 \%$. In addition, the industrial structure and employment structure have undergone a major change, and the demand for talent is in a diversified situation, resulting in the difficulties of many college graduates in meeting demands of the labor market. Seen from the subjectivity, during the employment, some students are unfit for a higher post but unwilling to accept a lower one, which directly impact their employment, or some find that it's too far from what they want in employment, or have no proper post for the skills of their own, so they decide to start a business "Fig. 1".

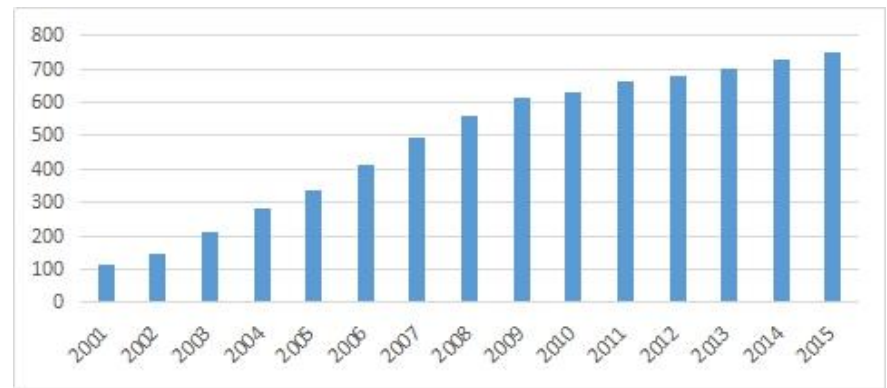

Fig. 1. The number of college graduates in China from 2001 to 2015 (unit: ten thousand)

2) Entrepreneurship instruction and policy support: Currently, facing the severe employment situation, the CPC Central Committee has released a series of policies and employment guidance measures to expand the employment as possibly as it can, and broaden the employment channels, and encourage independent entrepreneurship to ease the employment pressure so as to improve the employment structure. Colleges and universities have continuously strengthened the entrepreneurial knowledge training and independent entrepreneurship symposiums, exploited potentials of students to improve their awareness and interests to the independent entrepreneurship. Besides, the governments have also released preferential policies related to capital, taxation, administrative examination and approval and so on to further improve the entrepreneurial environment for college students, which have, to a large extent, eliminated the confusion and fear of college students in the independent entrepreneurship.

3) Self quality: Compared with those who are poorly educated, college students not only have deeper theoretical knowledge, but also higher overall quality. Especially they have greater curiosities and creation desires for the economic behaviors existing in the society, owning software conditions for self employment. Beside, college students own higher capabilities of practical application, good at combining theoretical knowledge with social practice, which help them achieve the market and technological innovation in social and economic fields so as to further promote the self employment.

Meanwhile, for college students who have established values and philosophy initially, the curiosities for the future and the power of examples have an extremely important role in forming the entrepreneurial motivation and relevant concepts. Studying and pursuing the spirits of famous entrepreneurs have been the drive for college students to realize personal ideals and values, as far as the entrepreneurial intention, college students have high entrepreneurial passion, owning entrepreneurial spirits of "plucky to attempt".

\section{B. Mechanism of Influencing Factors of Entrepreneurial Motivations of College Students in the New Normal}

Many literatures and researches show, the influencing factors of entrepreneurial motivations of college students are attributable to three aspects namely entrepreneurial environment, self efficiency and entrepreneurial quality. The article analyzes the mechanism of the factors in the following.

1) Entrepreneurial environment: Favorable entrepreneurial environment is an important factor for the entrepreneurship thought of college students, nowadays, it is very severe for employment, under the background of governmental support for business start-up of college students, the motivations of college students are formed and gradually consolidated. Compared with the business entrepreneurship environment of other classes, the environments of college students are mainly concentrated in the economic environment, policy environment and entrepreneurship atmosphere. First of all, currently the economy is in a diversified development, especially advent of the Internet time brings god-given business opportunities for entrepreneurs. The business type is no longer limited to traditional industries, the rising of new industries such as E-commerce, electronic logistics, virtual stores and so on, which have brought more opportunities for college students in business entrepreneurship. Second, the governments of all levels have released a variety of preferential policies, especially the venture loan funds and tax policies have helped college students solve the difficulty in finance, which have, to a large extent, eliminated the retreating in behavior and idea of college students because of the start-up capital in the development process. Third, the business 
atmosphere is a spiritual motivation that influences the entrepreneurship of college students, and a favorable atmosphere may helps college students achieve the motivations and raise the confidence of college students in business so as to solidify their business motivation and followup operation.

2) Self efficiency: Self efficiency is a self-evaluation on behaviors of him or her on the basis of subjective and objective judgments. So the self efficiency has a direct influence on individual perception of behaviors and motivation intensity. Generally, the self efficiency is an important factor influencing the business motivations of college students. The four process of self efficiency of college students in the entrepreneurship change and form the entrepreneurial motivations. First, during the entrepreneurship, the affirmation of college students on the capabilities of their own promotes the germination of entrepreneurship idea; Second, college students have higher senses of self efficiency, who have mature thought, contribution and insistence to the entrepreneurship, which further promote the formation of business motivation; the self efficiency of college students influences the further understanding and selection of entrepreneurial motivation, those who have higher self affirmation are more interested in the challenging entrepreneurship. Finally, when college students, facing difficulties in the business, retreat or are in negative impacts, those who have better senses of self efficiency may well deal with the mood, which further stabilize the business motivation of college students and exert their business operation.

3) Quality of entrepreneur: Quality of entrepreneur is a complex characteristic that the entrepreneur owns. For college students, the quality of an entrepreneur comprises the ability of innovation, needs for success, risk undertaking, internal concept control, independence and so on.

First, the ability of innovation: innovation is a key function in the entrepreneurship process, it means that the entrepreneur endows higher potentials to existing resources so as to create wealth. The innovation is the course through which college student change opportunities into business ideas, so the innovation is also a way for college students to achieve the business motivation. Besides, college students, driven by innovative ideas, constantly enhance the creativities so as to promote the realization of the fundamental goal of college students.

Second, personal characteristics: Personal characteristics such as education, independence, family economic conditions are also acting on the formation and realization of college students' business motivations. First of all, although the education is not a prerequisite for the business motivation, yet generally, the higher the educational background, the richer the theoretical knowledge will be, the deeper the economic and social understanding will be, the much clearer the business idea will be. Those who have higher independence are more willing to work for the goals of their own and choose the ways of their own to achieve the goals, so that the business motivation is much clearer. In addition, the family economic conditions, gender, personality and so on also have different influences on the business motivation, on the whole, the personal characteristics are important factors for college students in the formation of business motivations.

\section{RESEARCH DESIGN}

\section{A. Questionnaire}

This section mainly analyzes the factors influencing the business motivations of college students in the New Normal, taking the students of Jingdezhen Ceramic Institute, a typical college in entrepreneurship and employment in Jiangxi Province, as examples, and the data are based on the questionnaire.

The questionnaire began on April 1, 2015 and ended at the middle of Jul 2015. In order to make it easy for answering questions, an anonymous survey was carried out. In this survey 300 questionnaires were randomly distributed and 250 were collected. The collection rate of the questionnaires was $83 \%$. There were 200 questionnaires valid and 50 invalid, the effective rate was $80 \%$. According to the survey data, we have collected main data as shown in this article.

\section{B. Model Selection}

Based on the above analysis, the business motivations of college students are influenced by many factors, so this article chooses factor analysis for the empirical research. The factor analysis refers to a statistic method where the correlation between variables are reduced in dimension so as to reduce the complex variables to few variables able to save a large number of original information, and the few variables are used to the information and significance of the entire empirical data. The analysis procedures mainly include selecting variables, extracting common factors, performing factor rotation, and calculating factor scores. The model is given as follows:

$$
\begin{gathered}
\text { Set } \mathrm{X}_{\mathrm{i}}\left(\mathrm{i}=1_{2}, \ldots \ldots \mathrm{p}\right) \mathrm{P} \text { variables, if expressed as } \\
X_{\mathrm{i}}=\alpha_{\mathrm{i} 1} F_{1}+\alpha_{\mathrm{i2}} F_{2}+\cdots{ }_{\mathrm{w}}+\alpha_{\mathrm{im}} F_{\mathrm{m}} \quad(\mathrm{m} \leq \mathrm{p}) \\
{\left[\begin{array}{c}
X_{1} \\
X_{2} \\
\vdots \\
X_{p}
\end{array}\right]=\left[\begin{array}{cccc}
a_{11} & a_{12} & \ldots & a_{1 p} \\
a_{21} & a_{22} & \ldots & a_{2 p} \\
\vdots & \vdots & \ldots & \vdots \\
a_{p 1} & a_{p 2} & \ldots & a_{p m}
\end{array}\right]\left[\begin{array}{c}
F_{1} \\
F_{2} \\
\vdots \\
F_{\mathrm{m}}
\end{array}\right]+\left[\begin{array}{c}
\varepsilon_{1} \\
\varepsilon_{2} \\
\vdots \\
\varepsilon_{p}
\end{array}\right]} \\
\mathrm{X}=\mathrm{AF}+\varepsilon
\end{gathered}
$$

$F_{1}, F_{2}, \ldots, F_{m}$ called as common factors, whose coefficient are factor load, meeting:

$$
\begin{gathered}
\operatorname{cov}(F, \varepsilon)=0, F, \varepsilon \text { unrelated; } \\
\operatorname{cov}(F, \varepsilon)=E\left(F \varepsilon^{\prime}\right)=\left(\begin{array}{cccc}
E\left(F_{1} \varepsilon_{1}\right) & E\left(F_{1} \varepsilon_{2}\right) & \cdots & E\left(F_{1} \varepsilon_{1}\right) \\
E\left(F_{2} \varepsilon_{1}\right) & E\left(F_{2} \varepsilon_{2}\right) & \cdots & E\left(F_{2} \varepsilon_{2}\right) \\
\vdots & \vdots & \cdots & \vdots \\
E\left(F_{p} \varepsilon_{1}\right) & E\left(F_{1} \varepsilon_{2}\right) & \cdots & E\left(F_{p} \varepsilon_{p}\right)
\end{array}\right)=0
\end{gathered}
$$




$$
D(F)=\left[\begin{array}{llll}
1 & & & \\
& 1 & & \\
& & \ddots & \\
& & & 1
\end{array}\right]=1
$$

TABLE II.

KMO AND B ARTLETT INSPECTION

Namely $F_{1}, F_{2}, \ldots, F_{m}$ unrelated with each other, variance is 1 .

$$
D(\varepsilon)=\left[\begin{array}{llll}
\sigma_{1}^{2} & & & \\
& \sigma_{2}^{2} & & \\
& & \sigma_{0} & \\
& & & \sigma_{p}^{2}
\end{array}\right]
$$

Namely not related with each other, the variance may differ $\varepsilon_{i} \sim N\left(0, \sigma_{i}^{2}\right)$

According to the mathematical mode of factor analysis (formula (2), get a factor scoring function:

$$
F_{j}=\beta_{j 1} X_{1}+\beta_{j 2} X_{2}+\cdots+\beta_{j} X_{p}
$$

\section{Indicator Setting}

According to the intention of the article, the article sets main indicators influencing the entrepreneurship of college students, and the details are given as follows "Table I":

\begin{tabular}{|c|c|c|}
\hline $\begin{array}{l}\text { First-class } \\
\text { Indexes }\end{array}$ & Second-class Indexes & Meanings \\
\hline \multirow{3}{*}{$\begin{array}{l}\text { Entrepreneur } \\
\text { ial } \\
\text { Environment }\end{array}$} & $\begin{array}{l}\text { Level of economic } \\
\text { development }\end{array}$ & GDP in Jiangxi Province \\
\hline & $\begin{array}{l}\text { Entrepreneurship } \\
\text { guidance }\end{array}$ & Yes: 1, No: 0 \\
\hline & Lack of funds & $\begin{array}{l}\text { Proportion between fund support } \\
\text { and fund needed in } \\
\text { entrepreneurship }\end{array}$ \\
\hline \multirow[t]{2}{*}{$\begin{array}{l}\text { Self } \\
\text { efficiency }\end{array}$} & $\begin{array}{l}\text { Senses of difficulty in } \\
\text { realizing self value and } \\
\text { goals }\end{array}$ & Easy: 1 , General: 2 , Difficult: 3 \\
\hline & Affirmation on abilities & High Capability: 1 \\
\hline \multirow{5}{*}{$\begin{array}{l}\text { Personal } \\
\text { characteristi } \\
\text { cs }\end{array}$} & Ability of innovation & $\begin{array}{l}\text { Higher Capability in Innovation: } \\
\text { 1, General: } 2 \text {, Worse: } 3\end{array}$ \\
\hline & Education & $\begin{array}{l}\text { College: 1, Undergraduate: } 2 \text {, } \\
\text { Master's Degree or above: } 3\end{array}$ \\
\hline & Independence & High Independence: 1, Low: 0 \\
\hline & Gender & $\mathrm{M}: 1, \mathrm{~F}: 2$ \\
\hline & $\begin{array}{l}\text { Family economic } \\
\text { conditions }\end{array}$ & Based on Family Income \\
\hline
\end{tabular}

TABLE I. INDEX SYSTEM OF INFLUENCING FACTORS OF COLLEGE STUDENTS' ENTREPRENEURIAL MOTIVATION

\section{EMPIRICAL ANALYSIS}

\section{A. Analysis of Reliability and Validity}

Analyze the validity through the tests in the factor analysis procedures, in order to compact the model, the variance analysis result is shown in the next in the validity, the section only analyzes the results, the adaptability and variance analysis are used for the validity analysis, and the results are given as follow "Table II":

\begin{tabular}{|l|l}
\hline \multicolumn{1}{|c|}{ Component } & \multicolumn{1}{c}{ Value } \\
\hline Sample adequate Kaiser-Meyer-Olin & 0.747 \\
\hline Chi-square approximate value & 197.117 \\
\hline df & 45 \\
\hline Sig. & .000 \\
\hline
\end{tabular}

The KMO inspection may well test the correlation between variables, the closer the value is to 1 , the higher the correlation between variables, v.v. The data in the above table show, the KMO value in the questionnaire data is 0.747 , more than 0.6 , passing the Barlett Inspection of Sphericity with the significant level of 0.05 , which proves that the correlation between variables is higher, so seen from the adaptability analysis of the statistical results, the sampling data are applicable for factor analysis.

\section{B. Variance Analysis}

The Initial Eigenvalues is an indicator to measure the relative importance of factors in the factor analysis. The higher the Initial Eigenvalues is, the higher the importance will be, v.v. Seen from the above, the correlation matrix of variables have 3 characteristic roots greater than 1 , namely $3.785,2.512$, 2.142. The three factors together explain $84.39 \%$ of the factors influencing the business motivation of college students in Jiangxi Province, this is, in the factor analysis, three common factors can be used to explain $84.39 \%$ of the information in the original variables "Table III". 
TABLE III. VARIANCE RESUltS OF FACTOR ANALYSIS

\begin{tabular}{|c|c|c|c|c|c|c|c|c|c|}
\hline \multirow[b]{2}{*}{ Component } & \multicolumn{3}{|c|}{ Initial Eigenvalues } & \multicolumn{3}{|c|}{ Extraction Sums of Squared Loadings } & \multicolumn{3}{|c|}{ Rotation Sums of Squared Loadings } \\
\hline & Total & $\begin{array}{c}\% \text { of } \\
\text { Variance }\end{array}$ & $\begin{array}{c}\text { Cumulative } \\
\%\end{array}$ & Total & $\%$ of Variance & Cumulative \% & Total & $\begin{array}{c}\% \text { of } \\
\text { Variance }\end{array}$ & Cumulative \% \\
\hline$\overline{1}$ & 3.785 & 37.85 & 37.85 & 3.785 & 37.85 & 37.85 & 3.785 & 37.85 & 37.85 \\
\hline$\overline{2}$ & 2.512 & 25.12 & 62.97 & 2.512 & 25.12 & 62.97 & 2.512 & 25.12 & 62.97 \\
\hline 3 & 2.142 & 21.42 & 84.39 & 2.142 & 21.42 & 84.39 & 2.142 & 21.42 & 84.39 \\
\hline 4 & 0.521 & 5.21 & 89.6 & & & & & & \\
\hline$\overline{5}$ & 0.435 & 4.35 & 93.95 & & & & & & \\
\hline$\overline{6}$ & 0.245 & 2.45 & 96.4 & & & & & & \\
\hline 7 & 0.134 & 1.34 & 97.74 & & & & & & \\
\hline$\overline{8}$ & 0.102 & 1.02 & 98.76 & & & & & & \\
\hline 9 & 0.09 & 0.9 & 99.66 & & & & & & \\
\hline$\overline{10}$ & 0.034 & 0.34 & 100 & & & & & & \\
\hline
\end{tabular}

\section{Factor Analysis}

TABLE IV. COMPONENT ANALYSIS Results of Factor ANALysis

\begin{tabular}{|c|c|c|c|}
\hline \multirow{2}{*}{ Indexes } & \multicolumn{3}{|c|}{ Component } \\
\hline & 1 & 2 & 3 \\
\hline $\begin{array}{ll}\text { Level of } & \text { economic } \\
\text { development } & \end{array}$ & 0.232 & 0.915 & 0.332 \\
\hline Entrepreneurship guidance & 0.296 & 0.768 & 0.108 \\
\hline Lack of funds & 0.359 & 0.957 & 0.246 \\
\hline $\begin{array}{lccc}\text { Senses } & \text { of } & \text { difficulty } & \text { in } \\
\text { realizing } & \text { self } & \text { value } & \text { and } \\
\text { goals } & & & \end{array}$ & 0.044 & -0.244 & 0.851 \\
\hline Affirmation on abilities & 0.41 & 0.049 & 0.746 \\
\hline Ability of innovation & 0.245 & 0.085 & 0.917 \\
\hline Education & 0.763 & 0.028 & -0.03 \\
\hline Independence & 0.847 & 0.147 & 0.264 \\
\hline Gender & 0.876 & 0.357 & 0.311 \\
\hline Family economic conditions & 0.932 & 0.253 & 0.058 \\
\hline
\end{tabular}

Seen from the above table "Table III", the first common factor is focused on educational background, independence, gender, and family economic conditions, indicating that the first common factor is mainly a factor of individual characteristics. The second common factor is mainly reflected in the level of economic development, entrepreneurship guidance, lack of fund, which are factors of the entrepreneurship environment. The third common factor is mainly reflected in senses of difficulty in realizing self value and goals, affirmation on abilities and innovation, which proves the third factor is a factor of self efficiency.

\section{Evaluation on Complex Factor Scoring}

A factor rotation matrix is gotten from the above, and F1, F2 and F3 coefficients gotten via software, factor scoring and ranks of corresponding indicators can be obtained through the factor scoring formula:
TABLE V. FACTOR SCORE AND RANKING

\begin{tabular}{l|l|l}
\hline \multicolumn{1}{c|}{ Indexes } & \multicolumn{1}{|c}{ F } & \multicolumn{1}{c}{ Rank } \\
\hline Level of economic development & 1.25 & 1 \\
\hline Entrepreneurship guidance & 1.18 & 2 \\
\hline Lack of funds & 1.15 & 3 \\
\hline $\begin{array}{l}\text { Senses of difficulty in realizing self value and } \\
\text { goals }\end{array}$ & 1.07 & 4 \\
\hline Affirmation on abilities & 1.01 & 5 \\
\hline Ability of innovation & 0.88 & 6 \\
\hline Education & 0.79 & 7 \\
\hline Independence & 0.55 & 8 \\
\hline Gender & 0.49 & 9 \\
\hline Family economic conditions & 0.37 & 10 \\
\hline
\end{tabular}

Seen from the evaluation on the complex factor scoring, in the empirical analysis of this questionnaire, the lack of funds, namely the proportion between entrepreneurship support fund and the needed funds, is the most important factor influencing the business motivation, followed by the affirmation on abilities, then by the ability of innovation "Table V". It shows that the as far as the entrepreneurship for college students, the lack of funds is still the first factor to be considered for the business motivation, the less, the funds are, the lower the persistence of college students in entrepreneurship will be. The affirmation on ability and the ability of innovation have solved the confusion "what to do" and "what can be done" of college students in the entrepreneurship, making college students have special targets and direct business motivation. Second, in the individual characteristics, independence and educational background are the fourth and sixth major influencing factors, but family economic conditions and genders are low-level ones, indicating that in the individual characteristics, the independence has an active promotion in the formation of entrepreneurship of college students who have the thoughts and ideas of their own to make business judgment and behaviors so as to guide the conduct of business operation. In 
the entrepreneurial environment, though the entrepreneurial guidance has a certain influence on entrepreneurship of college students, yet compared to the level of economic development, the influence of entrepreneurial guidance on the entrepreneurial motivation of college students is lower; In terms of the self efficiency, compared to the factors as fund, the level of economic development in the entrepreneurial environment, the influence of self efficiency on the entrepreneurial motivation was slightly lower. The influence of senses of difficulty in realizing self value is more than that of the affirmation of abilities, which proves that within the entrepreneurial motivations of college students, the influence of senses of difficulty in realizing self value is bigger than that of self-ability, and the self ability has a direct influence on the formation and development of the entrepreneurial motivations.

\section{CONCLUSION AND SUGGESTIONS}

\section{A. Conclusion}

This article analyzes the influencing factors and mechanism of entrepreneurial motivations of college students in the New Normal through factor analysis, and thinks that the entrepreneurial environment, self efficiency and individual characteristics have a considerable role in the motivation mechanism of college students. Second, it creates an index system of influencing factors and analyzes the factors influencing the entrepreneurial motivation through factor analysis, and the results show that the lack of funds, namely the proportion between entrepreneurship support fund and the needed funds, is the most important factor influencing the business motivation, followed by the affirmation on abilities, then by the ability of innovation. In addition, the study also shows that, in terms of individual characteristics, college students have the thoughts and ideas of their own to make business judgment and behaviors so as to guide the conduct of business operation. In the entrepreneurial environment, the entrepreneurial guidance has a low influence on business motivation of college students. In terms of the self efficiency, in the entrepreneurial motivation, the influence of senses of difficulty in realizing self value is more than that of self-ability.

\section{B. Suggestions}

First, the state should vigorously develop the productive forces, accelerate the economic structural adjustment, and vigorously promote the tertiary industry, especially the development of the service industry so as to lay a sound economic foundation for the for entrepreneurship of college students

Second, increase the financial support for the entrepreneurship of college students, encourage the rational allocation of venture capital resources, relax the restriction to entrepreneurship of college students, and strengthen business guidance to college students.

Third, encourage the entrepreneurial spirits of college students, help them establish correct entrepreneurial motivations, form the entrepreneurship concepts of overcoming hardship, insisting and scientific, and strive to exploit the entrepreneurial potentials and innovation abilities, help college students realize self-worth and promote the harmonious development of the society.

\section{REFERENCES}

[1] Forbes, D P. The effects of strategic decision making on entrepreneurial self efficiency[J]. Entrepreneurship Theory and Practice, 2005, 29(5) : 599 - 626.

[2] Barbosa, S D, Gerhardt, M G, and Kickul, J R. The role of cognitive style and risk preference on entrepreneurial self efficiency and entrepreneurial intentions[J]. Journal of Leadership and Organizational Studies, 2007,13(4):86-104

[3] Hmieleski, KM, and Corbett, A C. The contrasting interaction effectsof improvisational behavior with entrepreneurial self efficiency on new venture performance and entrepreneur work satisfaction[J]. Journal of Business Venturing, 2008,23(3):482-496.

[4] Xing Wenzhi, Negative Selection of Motivations and Cognition Education for Entrepreneurship of College Students [J]. Statistics and Management, 2014(3):152-154

[5] Xiang Cheng, Study on Relaiotns bewteen Familiy Background and Entrepreneurial motivation of College Students $[\mathrm{J}]$. Guide to Business, 2015(10):129-130

[6] Wu Dongfang, Zhou Lian, Analysis of Entrepreneurial motivations of College Student in the New Normal [J]. Market Modernization Magazine 2015(10):259-260 